\title{
THE MOST COMMON CAUSES OF HONEYBEE POISONING
}

\author{
Radomir Ratajac ${ }^{1 *}$, Jelena Petrović ${ }^{1}$, Brankica Kartalović ${ }^{1}$, \\ Igor Stojanov ${ }^{1}$, Vladimir Polaček ${ }^{1}$
}

${ }^{1}$ Scientific Veterinary Institute "Novi Sad", Novi Sad, Republic of Serbia

\begin{abstract}
This paper discusses the most common causes of poisoning of honeybees and other pollinating insects that occur in the Republic of Serbia and the world as well. Some potential ways of pollinator exposure to different poisons and their intake are described. The paper also deals with the methods of testing and assessing toxicity of newly synthesized chemical substances and new formulations, classification of potential toxic substances according to their chemical characteristics and mechanism of action on the insects, symptoms of honeybee poisoning and risk assessment for the uses of pesticides. In the end, the paper looks into the methods of responsible use of pesticides and their toxicity in order to avoid bee poisoning.
\end{abstract}

Key words: honeybees, toxicity, pesticides

${ }^{1 *}$ Corresponding Author: ratajac@niv.ns.ac.rs 


\title{
NAJČEŠĆI UZROCI TROVANjA MEDONOSNIH PČELA
}

\author{
Radomir Ratajac ${ }^{1}$, Jelena Petrović ${ }^{1}$, Brankica Kartalović ${ }^{1}$, \\ Igor Stojanov ${ }^{1}$, Vladimir Polaček ${ }^{1}$
}

${ }^{1}$ Naučni institut za veterinarstvo „Novi Sad“, Novi Sad, Republika Srbija

\section{Kratak sadržaj}

U ovom radu razmatraju se najčešći uzroci trovanja medonosne pčele i drugih insekata oprašivača koja su evidentna u Republici Srbiji, kao i u svetu. Opisuju se mogući načini izloženosti oprašivača različitim otrovima i putevi unosa istih. Takođe, obrađuje se načini ispitivanja i procene toksičnosti novosintetisanih hemijskih supstanci i novih formulacija pesticida, klasifikacija potencijalnih toksičnih supstanci prema njihovim hemijskim karakteristikama i načinu delovanja na insekte, simptomi trovanja medonosnih pčela i procena rizika upotrebe pesticida. I na kraju, načine odgovorne upotrebe pesticida i mere koje se mogu preduzeti radi smanjenja trovanja pčela agro hemikalijama.

Ključne reči: pčele, toksičnost, pesticidi

\section{INTRODUCTION}

Honeybee (Apis mellifera) is a cosmopolitan species bred by beekeepers today for the production of commercially valuable products such as honey, wax, propolis, royal jelly, pollen and bee venom. The other reason for beekeeping is pollination, honeybees are the most successful and commercially exploited pollinators in agro-ecosystems. Nowadays, honeybees are bred using organic and conventional method of beekeeping, and in recent years, urban beekeeping has become more widespread in urban areas. The bees are continuously exposed to a wide range of stress factors such as: diseases of various etiologies, parasites, predators, chemical substances from natural and synthetic sources, etc. which are present in the environment (Ostiguy et al., 2019). Foraging worker bees are mostly exposed to adverse environmental influences because they can fly a distance of over $6 \mathrm{~km}$ in radius in search for food. In one day, these bees have 12 - 15 excursions and come into contact with pollutants from the environment (Beekman and Ratnieks. 2000). During the search for food, contaminants from the atmosphere remain on the bees' bodies and they are brought to the hive through pollen and nectar, where they reach other 
bees in the colony, and the brood. Therefore, worker bees, honey and pollen are often used as bioindicators of environmental pollution by various organic and inorganic compounds (Petrović et al, 2019; Kartalović et al., 2020). The use of a wide range of chemicals in agriculture, alone and / or in combination with other factors, such as elevated temperature, production of hybrid varieties with less pollen and nectar in flowers, has had a devastating effect on honeybees globally. Some of these examples are increased mortality of bee colonies that was recorded in 2006 in the United States (Henry et al., 2012). The mass extinction of bee colonies has been named Colony Collapse Disorder syndrome (CCD) (Retschnig et al., 2015). The collapse of bee colonies is a sudden disappearance of entire bee colonies, with no dead bees in the colony or hive and no kleptoparasites in the extinct hives, regardless of the excess food stored in them. The exact reason for this phenomenon has not yet been clearly explained, but it is believed that several stressors, acting individually and / or synergistically, contribute to the weakening of the health of bees, making them susceptible to the disease. Among systemic insecticides, newer generation pesticides, fipronil and neonicotinoids have been emphasized as the main causes of the collapse of bee colonies since the beginning of their application in the mid-90s of the last century. (Hoshi et al., 2014; Retschnig et al., 2015). This is why the world today is facing a great crisis, which has not only an ecological dimension, but also an economic one, because due to the reduction of the pollinator population, the yields of fruits, vegetables and cereals are decreasing, which directly leads to higher food prices, which affects consumers.

\section{EXPOSURE OF BEES TO PESTICIDES}

Different pesticide formulations are used to protect the plant from pests. Depending on the type of pesticide and the recommended method of use, they can be utilized for direct spraying of the plant or for the treatment of soil and seeds. Different methods of application and persistence of applied pesticides play a key role in the exposure of pollinating insects to these chemicals, and these are the main routes of exposure: a direct contact with the chemical during feeding on the treated plant; dust particles contaminated with pesticides, which stick to the bees or are carried to the hive by the wind; contamination of watercourses - surface waters with chemical agents used for field treatment; guttation water; honeydew (secretion); application of pesticides to untreated agricultural crops near the treated field and pesticide residues in pollen by seed treatment (Gaurava et al., 2020).

These different ways of exposing honeybees to pesticides allow contamination of bee colonies, but still the ways bees transmit these chemicals from the 
field are various and can be either oral, respiratory or dermal (cuticular).

Oral intake of chemical pesticides from the field is facilitated by foraging worker bees. The plants treated with insecticides produce contaminated nectar and pollen. Some studies have found the presence of high concentrations of various pesticide compounds, including insecticides, fungicides, miticides and herbicides in pollen samples of several crops (Krupke et al., 2012). The bees collect this flower resource carry them to colonies where they continue to use it to feed the bee brood (Wu et al.., 2011). The consequences can be numerous: foraging worker bees die during the collection and transport of contaminated pollen, bees in the hive die during storage and feeding, and broods die by consuming poisonous pollen, which leads to a complete collapse of the colony (Gaurava et al., 2020).

Pesticide formulations, such as dust and fumigants are sprayed by air and can be retained on the body surface of foraging worker bees or absorbed through the trachea in the concentrations sufficient to be toxic to bees (Gaurava et al., 2020). Inhalation of air contaminated with toxic substances causes various abnormalities, such as sudden changes in behavior and degradation of learning abilities (Karise and Mänd, 2015).

Foraging worker bees come into direct contact with pesticides while searching for food, and such chemicals can be lethal even in small quantities. Body wall - the chitinous cuticle of the thorax of honeybees is considered the main route of cuticular exposure to pesticides (OEPP/EPPO, 1992), although in some other studies it has been observed that insect wings are also a potential source of bee exposure (Poquet et al., 2015).

\section{CLASSIFICATION OF TOXIC SUBSTANCES}

Toxic chemicals can be classified by the levels of toxicity of substances for bees or based on the origin (pollutants, agrochemicals, medicines).

First, it should be pointed out that there is a great risk of using pesticides due to their acute toxicity to bees, which causes their mortality in a short period of time. Other very significant risks include sublethal effects that can adversely affect hive performance and colony survival in the long run. Pesticide toxicity varies from very high to very low. Substances with very low toxicity are practically non-toxic.

In order to define and categorize toxicity of pesticides during the development of substances, acute oral and contact toxicity tests are performed, according to the methods based on the guidelines issued by the European and Mediterranean Plant Protection Organizations (EPPO), i.e. The Organization for Economic Co-operation and Development (OECD, 1998, 1998a). These 
toxicity testing methods are laboratory methods designed to assess the acute oral and contact toxicity of plant protection products and other chemicals on adult worker bees. The method is particularly suitable for phased hazard assessment programs that pesticides pose to bees, based on a hierarchical order, from laboratory toxicity tests to semi-field and field tests. Acute oral and contact toxicity are adverse effects that occur no later than 96 hours after oral or contact administration of a single dose of the test substance. A dose is an amount of the test substance consumed or applied and is expressed as the mass of the test substance per individual ( $\mu \mathrm{g} / \mathrm{bee})$. The precise oral dose for each bee cannot be calculated because the bees are fed collectively, instead an average dose can be calculated (fully consumed test substance by the number of individuals - bees). Oral or contact LD50 (mean lethal dose) is a statistically derived single dose of a substance that can cause the death of $50 \%$ of animals when administered orally or when it comes into contact with it.

Based on the acute toxicity, the tested substances are classified into the following:

- Substances with very high toxicity to bees, acute toxicity to bees

$$
\text { LD50 }<2 \mu \mathrm{g} / \mathrm{bee}
$$

- Substances with moderate toxicity to bees, acute toxicity to bees

$$
\text { LD50 } 2 \text { - } 10.99 \mu \mathrm{g} / \text { bee }
$$

- Substances with low toxicity to bees, acute toxicity to bees

$$
\text { LD50 } 11 \text { - } 100 \mu \mathrm{g} / \mathrm{bee} \text {. }
$$

- Substances that are not toxic to bees, acute toxicity to bees

$$
\text { LD50 > } 100 \mu \mathrm{g} / \mathrm{bee} \text {. }
$$

Other methods for testing and assessing the toxicity of chemicals on bees have also been published:

- Guidance document on the honeybee (Apis mellifera L.) brood test under semi-field conditions (OECD, 2007). Principle of the test: Shortly before full flowering of the crop and some time before application of the test chemical, small healthy honeybee colonies are initially placed in tunnel tents. The bees are exposed in the tunnel for the period of flowering of the crop (e.g., at least 7 days after application of the product) after which the hives are placed outside the tunnel for the remaining of the study and are free to forage in the field. Over the period of at least 4 weeks after the initial brood assessment, the evaluation of the mortality of honeybees, flight activity, and condition of the colonies and development of the bee brood is done several times. Results are evaluated by comparing the treated colonies with the water treated colonies and with the reference chemical-treated colonies. 
- Guidance document on the honeybee (Apis mellifera L.) larval toxicity test, single exposure (OECD, 2013). Principle of the test: First instar synchronized larvae (i.e., larvae of the same age) are taken from the comb of three colonies and individually placed into 48 well-plates where a standardized amount of artificial diet is introduced. After three days, a single dose of the test chemical is administered to the larvae with the diet in a range of five increasing concentrations. Mortality was monitored for three next days and the $72 \mathrm{~h}$ LD50 is calculated for larvae.

- Guidance Document on honeybee (Apis mellifera L.) larval toxicity test, repeated exposure (OECD, 2016). Principle of the test: The preparation of the test and the selection of larvae is the same as for the single exposure. The chemical is administrated to the larvae during three days at a constant concentration equivalent to increasing test chemical doses per larva per day with the diet resulting in a cumulative dose on third day (for each treatment level) in a range of at least five increasing test concentrations, or at one concentration in case of a limit test. Mortality and other observations/ abnormal effects are recorded daily from during administration and on ninth and 16th day after administration. The NOEC (No Observed Effect Concentration) /NOED (No Observed Effect Dose) and, if data allows, the EC50/ED50, and/or any ECx/EDx are determined).

- Guidance Document on honeybee (Apis mellifera L.) chronic oral toxicity test (10-day feeding) (OECD, 2017). Principle of the test: Aqueous sucrose solution containing the test chemical is used to expose young bees, during a period of 10 days (ad libitum). Behavioral abnormalities and mortality are observed and recorded daily. The chronic effects of the test chemical are evaluated by comparing the results of the test chemical treated group to those of the respective control group. Following endpoints are determined by using this test: • LC50 (median Lethal Concentration) and the LDD50 (median Lethal Dietary Dose) values after 10 days of exposure. • NOEC and NOEDD (No Observed Effect Dietary Dose). In some cases, a limit test may be performed (e.g., when a test chemical is expected to be of low toxicity or when a test chemical is poorly soluble), in order to demonstrate that the NOEDD is greater than or equal to the limit dose tested, and the LDD50 is greater than the limit dose tested, if no effects are observed in the study.

- Guidance Document on honeybee (Apis mellifera L.) homing flight test, using single oral exposure to sublethal doses of test chemical (OECD, 2021). Principle of the test: This test method measures the effect of single sublethal oral doses of a test chemical (under controlled conditions) on the 
homing success of forager honeybees (under simulated field realistic conditions). Foragers are released $1 \mathrm{~km}$ away from the colony, and the homing success of chemically exposed versus non-exposed foragers is compared. This is achieved by monitoring the experimental bees with radio-frequency identification (RFID) tagging technology. The test is done in three replicates. The objective is to determine a NOED on homing success from all the doses of the chemical tested.

The second type of classification is based on the type of toxins that come from different sources.

\section{Environmental pollutants}

According to their origin, they are divided into natural and artificial-anthropogenic.

\section{Carbon dioxide}

The so-called global warming is changing meteorological factors and even the climate with unforeseeable consequences for the entire living world on the globe. The impact of pollutants on the survival of bees and other insects is also evident, with carbon dioxide potentially being toxic. The studies of the impact of carbon dioxide on honeybees have shown that $\mathrm{CO} 2$ can have some toxic effects on bee health at the individual and colony level. Changes were observed in the lifespan of bees (shorter), the amount of pollen collected during the flowering season (reduced), the narcotic effect in terms of reduced activity at elevated CO2 concentrations (Maini et al., 2010) and earlier oviposition of the queen bee (Gaurava et al., 2020).

\section{Heavy metals}

Due to the growing anthropogenic impact, heavy metals are one of the main pollutants in the environment. Unlike organic pollutants, heavy metals are not subject to degradation and they accumulate not only in the environment, but also in the living systems. The most common toxic elements known for their high levels of toxicity to living organisms, and its wide distribution, are cadmium, lead, mercury, arsenic, chromium, nickel, as well as micro elements such as copper, iron, zinc, manganese, cobalt and selenium. However, they are necessary for various biochemical and physiological processes in low concentrations, but when their concentrations are higher, they may become harmful. 
Heavy metals are among the most important potentially harmful pollutants and their presence can affect various physiological and metabolic processes. Toxicity of heavy metals is manifested by interaction with biomolecules in several ways: changes in the conformation of biomolecules, blocking of essential functional groups of biomolecules, replacement of essential metal ions in biomolecules, oxidative damage of biomolecules.

Various studies have shown that high concentrations of cadmium, copper and lead have a toxic effect on bees, which can lead to oxidative stress of individuals and disrupt the homeostasis of micro elements and detoxification of toxic metals, which then results in changes in the behavior and diet of bees. Cadmium and copper are actively absorbed by the root system of the plant from the soil and can be found in nectar and pollen, and bees usually come into contact with lead through contaminated surfaces where lead settles (Nikolić et al., 2016).

\section{Medicinal - active substances used in beekeeping}

Proper and timely use of veterinary preparations medications will not only protect bee colonies from diseases and pests, but will also prevent contamination of honey, wax, propolis and other bee products.

In the Republic of Serbia, the use of antibiotics in beekeeping is strictly forbidden because the consequences can be severe: destruction of saprophytic microflora and violation of bee colony immunity, concealment of diseases, frequent relapses, resistance to frequent administration of antibiotics, antibiotic residues and secondary metabolites in bee products (Kartalović et al., 2020).

To control the most widespread disease of honeybees caused by ectoparasite Varroa destructor in the Republic of Serbia, registered preparations based on: coumaphos (organophosphorus compound), fluvalinate (tau-fluvalinate pyrethroid), formic acid, as well as active substances of essential oils, camphor oil and the oil itself, menthol, eucalyptus oil (ALIMS, 2021). In addition, other organic acids such as lactic and oxalic acid are used. These chemicals have proved to be far more successful than other treatments, but at the same time their toxicity to bees has sometimes been neglected or studied less. However, the emergence of resistant mite populations has resulted in a sharp increase in the use of formic acid and oxalic acid in practice, as they are natural varocides that are also normally found in honey (Bogdanov, 2006). Organic acids are quite effective in controlling Varroa mites, but there haven't been many studies to determine their negative impact on honeybees. Schneider et al. (2012), they pointed out the harmful effects of organic acids on honeybees, which include 
the following: negative impact on brood development, lower physical fitness of the treated colony, increased mortality, reduced division of labor and reduced cleaning of hives and increased self-cleaning.

\section{Toxicity of formic acid}

Formic acid inhibits energy metabolism, i.e., the formation of hypoxic metabolism and histotoxic hypoxia (Keyhani and Keyhani, 1980). Also, formic acid can have an excitatory effect on the neurons of the parasite and penetrate through the thin exoskeleton of the parasite and thus cause their additional irritation and death. The selectivity of action is based on the difference in the thickness of the cuticula of the bee and a tick that parasitizes on it. Bees can tolerate 250 times the dose of formic acid compared to Varroa (ALIMS 2021a). When used in the recommended doses, i.e., according to the instructions for the drug, it is not harmful to bees. Data can be found in the literature that bees may experience increased buzzing and agitation, which usually disappears quickly. However, formic acid can cause a variety of toxicity symptoms in honeybees, including reduced worker bee life and lower brood survival rates (Underwood and Currie, 2003). It can have a toxic effect on the larvae in a covered brood, which then perish, and it can also have a detrimental effect on the open brood and hatching of bees. There is a possibility that (due to toxic effects) a certain number of queen bees might get lost. Other negative effects of formic acid treatment on bee colonies mainly include increased number of dead bees in front of the colony during the treatment period, rejection of queen bee, reduction in drone eggs. In addition, worker bees may be rejected from the colony and honey yield from treated colonies can be relatively lower (Gaurava et al., 2020).

\section{Oxalic acid toxicity}

The mechanism by which oxalic acid acts on Varroa has not yet been fully explained. It has been observed that treatment with this acid (sugar solution of oxalic acid) leads to an increase in apoptosis of middle intestine cells of bees, so it cannot feed and therefore dies of hunger (Gregorc and Škerl, 2007). Multiple use of oxalic acid, most commonly through sugar syrup, can lead to increased queen bee mortality and a reduction in the number of sealed broods (Higes et al., 1999). In the treated colonies, it has been observed that, in the early stages of life, worker bees show abnormal behavior that depends on the age of the individual. The behavior of bees, which depends on their age, is chronologically normal, but the intensity is different, and some stages appear 
earlier than normal. Treated bees show increased self-care, decreased activity, especially care bees (Gaurava et al., 2020).

\section{Agrochemicals - Pesticides}

Pesticides are chemical agents used to control plant pathogens, against harmful insects, nematodes, rodents and birds, algae and to control weeds or regulate plant growth, destroy fungi, and kill insects and other organisms that transmit infectious diseases in humans and animals.

\section{Insecticide toxicity}

Insecticides have been used since the early 1940's to effectively control pests and are usually divided according to their chemical composition and purpose. Insecticides from the group of organochlorine and organophosphorus insecticides, are significantly less used today or their use is prohibited (Petrović et al, 2021). Honeybees are susceptible to many insecticides, and various harmful effects of these insecticides are believed to be the main reason for the decline in the global bee population, the CCD (Retschnig et al., 2015).

\section{Organochlorine insecticides}

Organochlorine compounds are chemically derived from chlorine derivatives of aliphatic and aromatic hydrocarbons (DDT, Eldrin, Dieldrin, Lindane, etc.). The characteristic of these compounds is that they are very lipophilic, and they accumulate in tissues rich in lipids, which leads to bioaccumulation and an increase in the concentration of pesticides through food chain - biomagnification (Petrović et al., 2021). Biological activity of organochlorine compounds is aimed at stimulating the nervous system, resulting in disorders in the transmission of nerve impulses. Due to their ability to accumulate and remain in the environment for a long time (POPs - persistent organic pollutants), most organochlorine insecticides are banned for use and withdrawn from the market.

\section{Organophosphate (OP) and carbamate insecticides}

Two widely used groups of insecticides are organophosphates (esters of phosphoric acid: methyl parathion, phorate, coumaphos, etc) and carbamates (organic compounds derived from carbamic acid: carbaryl, carbofuran, aldicarb, etc). Both groups of insecticides affect insects in a similar way as acetyl 
cholinesterase (AChE) inhibitors (OP irreversible, carbamates reversible), resulting in severe hyperexcitation and convulsions, leading to paralysis and death (Dulin et al., 2012). The values of LD50 topical toxicity for the active substances of these two classes of insecticides are in a wide range (0.094 (oxamyl) to 20 (coumaphos) $\mu \mathrm{g} / \mathrm{bee}$ ) (EPA, 2021). Toxic symptoms of organophosphate are irregular and disoriented movement of bees, joined wings, enlarged abdomen, tongue sticking out with regurgitation of food, and death. Toxic symptoms of carbamate include improper movement of bees, with swelling (numbness) and paralysis, interruption in the brood cycle, while queen bee stops laying eggs, and eventually most bees die in colonies (Gaurava et al., 2020).

\section{Pyrethroids}

Pyrethrin insecticides, produced from the flowers of pyrethrum (Chrisanthemum inerariaefolium) are a widely used group of insecticidal compounds. Although pyrethrin is of natural origin, it is known that these chemicals are very toxic to bees $\left(\mathrm{LD}_{50}=0.022-0.21 \mu \mathrm{g} / \mathrm{bee}\right)(\mathrm{EPA}, 2021)$. In addition to pyrethrin and pyrethroids insecticides show their effect on parasites by altering the permeability of voltage sodium channels in nerve cell membranes, leading to membrane depolarization, i.e., hyperexcitability, and as a result, a rapid paralysis of individuals ("knock down effect") and death. In addition, they can act on the postsynaptic membrane and on nicotine, GABA (gamma-aminobutyric acid) and glutamine receptors, as well as on voltage-gated calcium channels. Bees have greater tolerance to some pyrethroids due to their rapid detoxification by the cytochrome P450 enzyme. Tau-fluvalinate, a widespread miticide, is less toxic and it is safer for bees, but in higher concentrations, this chemical has a negative effect on the health of different classes of bee colonies, as it causes temporary disturbance and weight loss in queen bees (Haarmann et al., 2002). It has also been observed that drones are exposed to tau-fluvalinate during development with less chance of reaching sexual maturity (Rinderer et al., 1999). Toxic symptoms of synthetic pyrethroids are improper movement of bees and paralysis, regurgitation of food intake, and eventually many bees die between the area where they look for food and the colony (Gaurava et al., 2020).

\section{Neonicotinoids}

In the past, tobacco extract was used for protection against pests, but due to its toxicity, it is now not used almost at all. In the studies that dealt with the toxicity of nicotine, it was found that there is $23 \mathrm{ppm}$ of nicotine in the pollen 
of the tobacco plant (Nicotiana tabacum) and $0.1-5 \mathrm{ppm}$ in nectar. It was also found that adult bees successfully detoxify nicotine in nectar, while larvae are sensitive to nicotine and usually die in the third or fourth stage of development at the concentration of $50 \mathrm{ppm}$ (Singaravelan et al., 2006). Nowadays, there are more modern protective substances, some of which are chemically similar to nicotine, but have greater efficiency in the fight against harmful insects, and relatively lower toxicity to the human body - neonicotinoids: nitroguanidine neonicotinoids; nitromethylene neonicotinoids and pyridyl methylamine neonicotinoids. There are many advantages to neonicotinoids compared to pyrethroid, organophosphate and carbamate insecticides and people are increasingly replacing them worldwide. Neonicotinoids act similarly to natural products - nicotine, acetylcholine, epibatidine, as agonists of postsynaptic nicotinic acetylcholine receptors (nAChR) of insects. Neonicotinoids are one hundred times more selective for $\mathrm{nAChR}$ insects than vertebrates (Tomizawa and Casi$\mathrm{da}, 2005)$. Some toxicity studies of these compounds have indicated that these insecticides are potentially very dangerous and may be one of the causes of CCD (Hoshi et al., 2014). Nitroguanidine neonicotinoids have been reported to be highly toxic to bees, with toxicity levels ranging from 0.0038 (imidacloprid) to 0.024 (thiamethoxam) $\mu \mathrm{g} / \mathrm{bee}(\mathrm{EPA}, 2021$ ). Insecticides from the nitroguanidine group also show their toxic effect by reducing the ability of queen bees to return to the hive. The cyano-substituted neonicotinoids exhibited a much lower toxicity with LD50 values for acetamiprid and thiacloprid of 7.1 and $17.94 \mu \mathrm{g} / \mathrm{bee}$, respectively (EPA, 2021). This relatively low toxicity is probably a result of detoxification under the impact of the cytochrome P450 enzyme (Blacquiére et al., 2012).

In 2013, the European Commission (EU Regulation No. 485/2013) and Serbia temporarily introduced a restriction on the use of clothianidin, thiamethoxam and imidacloprid in order to reduce their impact on bees. The use and sale of seeds treated with plant protection products containing these active substances, except for seeds used in greenhouses, is prohibited.

\section{Phenylpyrazoles}

The main representative of this group of insecticides is fipronil, a broadspectrum insecticide. It was manufactured in 1987 and originally developed for the use in pest control in agriculture and for public health (Zhang et al., 2016). It acts by inhibiting the GABA complex (main inhibitory neurotransmitter) and by binding to chlorine channels thus blocking pre and postsynaptic transfer of chloride ions across the cell membrane. In this way, it in- 
hibits the transmission of nerve impulses between nerve cells, which leads to uncontrolled activity of the central nervous system and insect death by hyperexcitation (Islam and Lynch, 2012). Fipronil has a strong affinity towards invertebrate GABAergic receptors, which makes it more toxic to insects than to mammals (Narahashi et al., 2007). Fipronil is very toxic to bees (LD50 = $0.0218 \mu \mathrm{g} /$ larvae, $0.004 \mu \mathrm{g} / \mathrm{bee}$ ) (EPA, 2021), causing restlessness, tremor, and paralysis. Bees that were exposed to lethal or sublethal doses showed reduced motor activity. Exposure of bee colonies to sublethal concentrations of fipronil led to a reduced number of hatched eggs, a smaller number of worker bee eggs and fewer larvae and pupae, while adult bees were lethargic, colonies were becoming slowly weaker, and bees were leaving the hive (Zaluski et al., 2015).

The European Commission (EU Regulation No. 781/2013a) and Serbia introduced a restriction on the use of fipronil due to the high risk for bees in 2013. The use and sale of seeds treated with plant protection products containing fipronil is prohibited, except for the seeds used in greenhouses and for some types of onions and cabbage that are grown in fields and harvested before flowering.

\section{Fungicide toxicity}

It is generally accepted that fungicides are not toxic to bees, so they are sometimes applied during the flowering of a plant that coincides with the maximum activity of bees, as residues are often found in the pollen of honeybees (Kubik et al., 1999). But beekeepers have reported brood losses in the larval and pupae stages that coincide with the use of fungicides during flowering. Malformations also occur, there are young bees without wings, which gather at the bottom and at the entrance of the hive. It has also been found that the application of fungicides causes hypothermia in adult honeybees (Gaurava et al., 2020). Toxicity levels for various fungicides range from LD50 10 to as much as $>200 \mu \mathrm{g} /$ bee $(\mathrm{EPA}, 2021)$.

\section{Herbicide toxicity}

The level of herbicide toxicity is known to be very low for most insects and therefore these pesticides are applied without any insect restrictions. High concentrations of herbicides can have toxic effects on honeybees, $\mathrm{LD}_{50}$ values vary in the range $15->100 \mu \mathrm{g} / \mathrm{bee}$ (EPA, 2021). For a widely used herbicide, paraquat has been reported to be toxic to bees in the laboratory, causing a tenfold shorter life span of a worker bee than normal when $15 \mu \mathrm{g}$ of active 
substance per bee is applied. When treating crops at a concentration of $4.5 \mathrm{~kg}$ of active substance/ha, bee death occurs within 3 days. On the other hand, the use of herbicides can reduce the number of plant species thus reducing grazing - flower resources (Gaurava et al., 2020).

\section{SYMPTOMS OF BEE POISONING}

Symptoms of bees poisoning will depend on the toxicity of the substance, duration, and place of exposure of bees and colonies:

- If bees are exposed directly in the field to pesticides of high toxicity, during food collection, many dead bees and other insects will be found in the fields, whereas only a part of them will manage to return to their hives. Hives themselves might be located nearby the fields treated with highly toxic chemicals for bees, which sometimes causes massive death of entire colonies. Usually, stronger colonies will be affected more than weaker ones, as they are more active in collecting food.

- The presence of a large number of dead and dying bees in front of the hive, and at the entrance to the hive is one of the obvious signs that the foraging bees were in contact with the toxic substance. Also, sticky, thick, dark liquid may be present at the entrance due to regurgitation of collected nectar in poisoned bees.

- Bees can change their behavior due to contact with contaminated food and be very upset, so they can be very aggressive when examined by beekeepers.

- In addition, the following prolong symptoms may occur, with less toxic substances and / or less exposure to toxic substances: twitching movements, dizziness, slow activity, crawling and paralysis of bees, loss of ability to fly and usually death occurs in only a few days (2 - 3 days).

- When inspecting the hive, the following signs may indicate bee intoxication: poor egg-laying patterns or abnormal queen bee behavior, disruption of the brood cycle (the stage of young bees) or the variegated of the brood (Gaurava et al., 2020).

\section{RISK ASSESSMENT OF PESTICIDE USE}

Risk assessment of pesticide effects on the bee colony is complex and cannot be based solely on data on oral and contact acute toxicity expressed through the LD50, which is a classic toxicological test to investigate the effects of pesticides on bees (OEPP/EPPO, 1992). This approach to testing the effects of pesticides on bees is necessary, but on the other hand, it is not sufficient for 
testing pesticides that have a different route of exposure into the bee, i.e., bee colony, a different mechanism of action and some of them could cause harmful chronic effects on bees. Therefore, more information on the toxicity of pesticides to adult bees and their developmental forms (testing and sublethal doses, etc.), provides a better insight into the real risk potential of their use for bee colonies. Therefore, Colin et al. (2004) believe that exposure of the entire bee colony to pesticides, through a chronic toxicity test could quantify the effect of pesticides on bees way better, and above all systemic insecticides. In order to better understand the impact of pesticides on bees and the bee colonies, testing the effect of pesticides on bee larvae grown in vitro is also being conducted (Aupinel et al., 2005).

The following indicators should be taken into consideration for bees' risk assessment (Mirjanić and Mitrić, 2012):

- For adults: LD15, LD50; LC15, LC50; LDD50; NOED, NOEC and NOEDD

- For larvae: LD50; LC50; NOEL - No Observable Effect Level and LOECLowest Observed Effect Concentration

- Pesticide application rate: PEC- Predicted Environmental Concentration; PNEC- Predicted No Effect Concentration; TER - Toxicity Exposure Ratio $($ TER $=$ LD50/PEC)

- HQ1- hazard quotient (HQ1=application rate/LD50); HQ2 for adults (PEC/NOEC); HQ3 for larvae (PEC /NOEC)

Despite all these data collected during the research of a newly synthesized substance or new formulation, risk assessment in field conditions is sometimes impossible to determine, because the impacts of various factors, which are important for the exposure of bees as individuals or as colonies increase tenfold, starting with the assessment of the amount of pesticides used per unit area, manner and time of use, atmospheric conditions, the condition of bees and colonies, etc... Sometimes, some important facts are missing. This all implies that the research in the field of assessment of the impact of pesticides on bees must continue in every respect, especially in development of software programs that can encompass all databases on pesticide toxicity and their interaction and bee biology and provide the most objective insight into toxicodynamic and toxicokinetic model for bees. 


\section{MEASURES THAT CAN BE TAKEN IN ORDER TO REDUCE BEE POISONING BY AGROCHEMICALS}

Measures that can be taken in order to reduce bee poisoning by agrochemicals are the following:

- Pesticides that are registered on our market should be used exclusively according to the manufacturer's instructions, in the prescribed amount in quiet weather and prevent "drift" of pesticides, i.e., application to surrounding area, do not apply above $25^{\circ} \mathrm{C}$, and use them only when there is a need for them.

- Do not apply pesticides when the crop is in the flowering stage. The use of pesticides (toxic to bees) during flowering is prohibited according to the Law of Plant Protection Products (Official Gazette of RS, 17/2019). Avoid spraying weeds in during the flowering phase or remove weed flowers before the treatment.

- Prevent surface water pollution by rinsing sprinklers and disposing of used packaging of protective agents in canals and watercourses, etc., because in this way the water used by bees in the summer to cool the colony in the hive is contaminated.

- Farmers who spray plants need to inform the beekeepers or beekeeping associations in the surrounding area about it at least two days before the treatment. All beehives located less than $5 \mathrm{~km}$ away from the treated area are endangered. The informed beekeepers must move their hives or close them. A beekeeper is obliged to display a board with his address and telephone number next to the bee yard. Due to the frequent poisoning of bees in cultivated orchards, in order to avoid misunderstandings, damage and death of bee colonies that can occur during pollination, so it is necessary to define the relations between fruit growers and beekeepers in advance.

- In order to protect the bees, and avoid direct contact, it is best to spray in the early evening (most pollinators are active from 8 am to $5 \mathrm{pm}$ ), which would allow easily degradable substances to partially decompose during the night, or 2 hours after the sunset or up to two hours before sunrise.

- It is important to make the right choice of pesticides in terms of less toxicity for bees, optimal dosage, and optimal choice of formulation, avoid the use of microencapsulated insecticide formulations, as well as powder forms, ultra-small volume formulations because they are much more available to individuals and bee colonies. The use of liquid formulations, emulsions, granular pesticide formulations is much less dangerous, because the potential for bee exposure is reduced (Gaurava et al., 2020). 


\section{CONCLUSION}

All the above mentioned indicates that bees have great ecological, and economic importance, and that is why their conservation is crucial and of great significance. In the last few decades, bees have been exposed to increased levels of pollution, which alongside poor nutrition and pathogens contribute to the weakening of bee populations in Europe and the world. Since there is no assessment of the impact of a large number of stressors on bees, it is recommended to work on identification of these factors and their interaction, as well as the assessment of lethal / sublethal effects of various pollutants on bees. The stress to which bees are exposed is the impact of the environment which disturbs or weakens the structure and functioning of the organisms and endangers their survival. The stress response can be studied at different levels of organization: molecular, cellular, histological, physiological, environmental, and social. Studying the mechanisms of adaptation to stressful and extreme environmental conditions provides a basis for solving health problems, enables toxicological risk assessment and the use of bioindications to monitor global changes in the environment.

The pesticides used in agriculture, environmental pollutants, as well as medicines and other substances used in health care and hygiene of bee colonies pose a constant risk in beekeeping, not only because they can endanger the honeybee and the bee colony, but also because that they can contaminate bee products. Proper application of registered pesticides and drugs and compliance with the norms of good agronomic and veterinary practice reduces the possibility of pesticides coming into contact with the bees, i.e., side effects. Systemic insecticides are particularly dangerous and therefore it is necessary to work on the constant development of pesticide risk assessment for bees and follow modern legislation in the field of pesticide toxicology.

Furthermore, farmers and beekeepers need to be continuously educated in order to raise awareness about the ecological and economic importance of bees, harmfulness of various chemicals used in agriculture and beekeeping, with the aim to preserve and develop bee communities, i.e. the biocenosis.

\section{ACKNOWLEDGEMENT}

This study was funded by Ministry of Education, Science and Technological Development of Republic of Serbia by the Contract of implementation and funding of research work of NIV-NS in 2021, Contract No: 451-03-9/2021-14/200031 and was also supported by Provincial Secretariat for Agriculture, Water Management and Forestry of Vojvodina, Contract No: 104-401-4672/2021/01. 


\section{Author's Contribution:}

RR, JP and VP made contributions to conception of the article, involved in data collection and drafting the manuscript. RR, JP and BK contributed with data about residue in bee products (organic and inorganic compounds) and toxicity of chemicals use in agriculture to bees, IS and VP did data processing about diseases of bees various etiologies. Revised the manuscript critically and together with RR, JP, BK, IS and VP prepared the final draft of the manuscript. All authors read and approved the final manuscript

\section{Competing interest}

The authors declare that they have no competing interests.

\section{REFERENCES}

1. ALIMS.2021. Search for veterinary medicines, Available at: https://www. alims.gov.rs/eng/veterinary-medicines/search-for-veterinary-medicines/, Accessed 30.11.2021.

2. ALIMS.2021a. Furmitom, Summary of product characteristics, Available at: https://www.alims.gov.rs/ciril/files/lekovi_veterina/smpc/323-0100033-18-001.pdf, Accessed 30.11.2021.

3. Aupinel P., Fortini D., Dufour H., Taséi J.N., Michaud B. 2005. Improvement of artificial feeding in a standard in vitro method for rearing Apis mellifera larvae, Bulletin of Insectology. 58,2, 107-111.

4. Beekman M., Ratnieks F.L.W. 2000. Long-range foraging by the honey-bee, Apis mellifeera L. Functional Ecology 14, 4, 490-496. doi: 10.1046/j.13652435.2000.00443.x.

5. Blacquiére, T., Smagghe, G., van Gestel, C.A.M., Mommaerts, V. 2012. Neonicotinoids in bees: a review on concentrations, side-effects and risk assessment. Ecotoxicology, 21, 973-992. doi: 10.1007/s10646-012-0863-x.

6. Bogdanov S. 2006. Contaminants of bee products. Apidologie. 37,1-18. doi: 10.1051/apido:2005043.

7. Colin M.E., Bonmatin J.M., Moineau I., Gaimon C., Brun S., Vermandere J.P. 2004. A method to quantify and analyze the foraging activity of honey bees: relevance to the sublethal effects induced by systemic insecticides, Archives of Environmental Contamination and Toxicology. 47, 3, 387395. doi: 10.1007/s00244-004-3052-y.

8. Dulin F., Halm-Lemeille M.P., Lozano S., Lepailleur A., Sopkova-de Oliveira Santos J., Rault S., Bureau R. 2012. Interpretation of honeybees contact 
toxicity associated to acetylcholinesterase inhibitors. Ecotoxicology and Environmental Safety. 79, 13-21. doi: 10.1016/j.ecoenv.2012.01.007

9. EPA, United States Environmental Protection Agency, OPP Pesticide Ecotoxicity Database, Available at: https://ecotox.ipmcenters.org/index. $\mathrm{cfm}$ ?menuid=5 Accessed 30.11.2021.

10. EU Commission. 2013. Commission Implementing Regulation (EU) No 485/2013 of 24 May 2013 amending Implementing Regulation (EU) No $540 / 2011$, as regards the conditions of approval of the active substances clothianidin, thiamethoxam and imidacloprid, and prohibiting the use and sale of seeds treated with plant protection products containing those active substances. Official Journal of the European Union, 139, 25.5.2013, 12-26

11. EU Commission. 2013a. Commission Implementing Regulation (EU) No 781/2013 of 14 August 2013 amending Implementing Regulation (EU) No $540 / 2011$, as regards the conditions of approval of the active substance fipronil, and prohibiting the use and sale of seeds treated with plant protection products containing this active substance. Official Journal of the European Union, 219, 15.8.2013, 22-25.

12. Gaurava K., Swoyam S., Rukesh P.d Kodigenahalli N. 2020. Detailed Review on Pesticidal Toxicity to Honey Bees and Its Management, In: Modern Beekeeping - Bases for Sustainable Production, Ed. Ranz Rebolledo. E.R., IntechOpen, doi: 10.5772/intechopen.91196. Available at: https:// www.intechopen.com/chapters/71161

13. Gregorc A and Škerl M.I. 2007. Toxicological and immunohistochemical testing of honeybees after oxalic acid and rotenone treatments. Apidologie, 38, 3, 296-305. doi:10.1051/apido:2007014.

14. Haarmann T., Spivak M., Weaver D., Weaver B., Glenn T. 2002. Effects of fluvalinate and coumaphos on queen honey bees (Hymenoptera: Apidae) in two commercial queen rearing operations. Journal of Economic Entomology. 95, 1, 28-35. doi:10.1603/0022-0493-95.1.28.

15. Henry M., Beguin M., Requier F., Rollin O., Odoux J.F., Aupinel P., Aptel J., Tchamitchian S., Decourtye A. 2012. A common pesticide decreases foraging success and survival in honey bees. Science, 336, 6079, 348-350. doi: $10.1126 /$ science. 1215039 .

16. Higes M., Meana A., Suárez M., Llorente J. 1999. Negative long-term effects on bee colonies treated with oxalic acid against Varroa jacobsoni Oud. Apidologie. 30, 4, 289-292. doi: 10.1051/apido:19990404.

17. Hoshi N., Hirano T., Omotehara T., Tokumoto J., Umemura Y., Mantani Y., Tanida T., Warita K., Tabuchi Y., Yokoyama T., Kitagawa H. 2014. Insight into the mechanism of reproductive dysfunction caused by neonicotinoid 
pesticides. Biological and Pharmaceutical Bulletin. 37, 9, 1439-1443. doi: 10.1248/bpb.b14-00359.

18. Islam R. and Lynch J. W. 2012. Mechanism of action of the insecticides, lindane and fipronil, on glycine receptor chloride channels. British Journal of Pharmacology, 165, 8, 2707-2720. doi: 10.1111/j.1476-5381.2011.01722.x.

19. Karise R and Mänd M. 2015. Recent insights into sublethal effects of pesticides on insect respiratory physiology. Insect Physiology. 5, 31-39. doi: 10.2147/OAIP.S68870.

20. Kartalović B., Petrović J., Ratajac R., Vidaković S., Stojanović D., Mirčeta J., Đorđević V.. 2020. Survey of sulfonamides in meat and honey in Vojvodina market, Serbia. Journal of Food Safety and Food Quality, 71, 1, 10-15, doi: 10.2376/0003-925X-71-10.

21. Keyhani J and Keyhani E. 1980. EPR study of the effect of formate on cytochrome C oxidase. Biochemical and Biophysical Research Communications, 92, 1, 327-333. doi: 10.1016/0006-291X(80)91556-9.

22. Krupke C.H., Hunt G.J., Eitzer B.D., Andino G., Given K. 2012. Multiple routes of pesticide exposure for honey bees living near agricultural fields. PLoS One. 7, 1, e29268. doi: 10.1371/journal.pone.0029268.

23. Kubik M., Nowacki J., Pidek A., Warakomska Z., Michalczuk L., Goszczyñski W. 1999. Pesticide residues in bee products collected from cherry trees protected during blooming period with contact and systemic fungicides. Apidologie. 30, 6, 521-532. doi: 10.1051/apido:19990607.

24. Maini S., Medrzycki P., Porrini C. 2010. The puzzle of honey bee losses: A brief review. Bulletin of Insectology. 63, 1, 153-160.

25. Mirjanić G. and Mitrić S. 2012. Effect of pesticides on honeybees, In: Proceedings. 47th Croatian and 7th International Symposium on Agriculture, Opatija, Croatia, 605-609.

26. Narahashi T., Zhao X., Ikeda T., Nagata K., Yeh J.Z. 2007. Differential actions of insecticides on target sites: basis for selective toxicity. Human and Experimental Toxicology. 26, 4, 361-366. doi:10.1177/0960327106078408.

27. Nikolić T, Kojić D, Orčić S, Batinić D, Vukašinović E, Blagojević D., Purać J. 2016. The impact of sublethal concentrations of $\mathrm{Cu}, \mathrm{Pb}$ and $\mathrm{Cd}$ on honey bee redox status, superoxide dismutase and catalase in laboratory conditions. Chemosphere, 164, 98-105. doi: 10.1016/j.chemosphere.2016.08.077.

28. OECD - Organisation for Economic Co-operation and Development. 1998. Honeybees, Acute Oral Toxicity Test (OECD/OCDE Test No. 213), Available at: https://doi.org/10.1787/9789264070165-en.

29. OECD - Organisation for Economic Co-operation and Development. 1998a. Honeybees, Acute Contact Toxicity Test (OECD/OCDE Test No. 214), Available at: https://doi.org/10.1787/9789264070189-en. 
30. OECD - Organisation for Economic Co-operation and Development. 2007. Guidance document on the honey bee (Apis mellifera L.) brood test under semi-field conditions ENV/JM/MONO(2007)22, Available at: https://www.oecd.org/officialdocuments/publicdisplaydocumentpdf/?cot $\mathrm{e}=\mathrm{env} / \mathrm{jm} / \mathrm{mono}(2007) 22 \&$ doclanguage $=e n$.

31. OECD - Organisation for Economic Co-operation and Development. 2013. Guidance document on the Honey bee (Apis mellifera L.) larval toxicity test, single exposure (OECD/OCDE Test No. 237), Available at: https://doi.org/10.1787/9789264203723-en .

32. OECD - Organisation for Economic Co-operation and Development. 2016. Guidance Document on Honey Bee (Apis mellifera L.) Larval Toxicity Test, Repeated Exposure ENV/JM/MONO(2016)34, Available at: https://one.oecd.org/document/ENV/JM/MONO(2016)34/en/pdf.

33. OECD - Organisation for Economic Co-operation and Development. 2017. Guidance Document on Honey bee (Apis mellifera L.) chronic oral toxicity test (10-day feeding), (OECD/OCDE Test No. 245), Available at: https://doi.org/10.1787/9789264284081-en.

34. OECD - Organisation for Economic Co-operation and Development. 2021. Guidance Document on Honey Bee (Apis mellifera L.) homing flight test, using single oral exposure to sublethal doses of test chemical, ENV/ CBC/MONO(2021)7, Available at: https://www.oecd.org/officialdocuments/publicdisplaydocumentpdf/?cote=ENV-CBC-MONO(2021)7\%20 \&doclanguage $=$ en.

35. OEPP/EPPO. 1992. Guideline on test methods for evaluating the side effects of plant protection products on honeybees, Bull. OEPP/EPPO 22, 201-215.

36. Ostiguy N., Drummond F.A., Aronstein K., Eitzer B., Ellis J.D., Spivak M., Sheppard W.S. 2019. Honey bee exposure to pesticides: A four-year nationwide study. Insects, 10,1, 13. doi: 10.3390/insects10010013.

37. Petrović J., Kartalović B., Ratajac R., Spirić D., Djurdjević B., Polaček V., Pucarević M. 2019. PAHs in different honeys from Serbia, Food Additives and Contaminants: Part B, 12, 2, 116-123. doi: 10.1080/19393210.2019.1569727.

38. Petrović J., Kartalović B., Mirčeta J., Prodanov-Radulović J., Ratajac R., Mastanijević K. 2021. Organochlorine pesticides and NDL-PCBs in wild boars from flatland region with intensive agricultural activities. Food additives and contaminants: part B, 1-11. doi:10.1080/19393210.2021.1976287.

39. Poquet Y., Kairo G., Tchamitchian S., Brunet J.L., Belzunces L.P. 2015. Wings as a new route of exposure to pesticides in the honey bee. Environmental Toxicology and Chemistry. 34, 9, 1983-1988. doi: 10.1002/etc.3014. 
40. Republic of Serbia. 2019. Law of Plant Protection Products (Official Gazette of RS,41/2009, 17/2019).

41. Retschnig G., Williams G.R., Odemer R., Boltin J., Di Poto C., Mehmann M.M., Retschnig P., Winiger P., Rosenkranz P., Neumann P. 2015. Effects, but no interactions, of ubiquitous pesticide and parasite stressors on honey bee (Apis mellifera) lifespan and behaviour in a colony environment, Environmental Microbiology, 17, 11, 4322-4331. doi: 10.1111/1462-2920.12825.

42. Rinderer T.E., De Guzman L.I., Lancaster V.A., Delatte G.T., Stelzer J.A. 1999. Varroa in the mating yard. I. The effects of Varroa jacobsoni and apistan on drone honey bees. American Bee Journal, 139, 2, 134-139.

43. Schneider S, Eisenhardt D, Rademacher E. 2012. Sublethal effects of oxalic acid on Apis mellifera (Hymenoptera: Apidae): Changes in behaviour and longevity. Apidologie, 43, 2, 218-225. doi: 10.1007/s13592-011-0102-0.

44. Singaravelan N., Inbar M., Ne'eman G., Distl M., Wink M., Izhaki I. 2006. The effects of nectar-nicotine on colony fitness of caged honeybees. Journal of Chemical Ecology. 32, 1, 49-59. doi: 10.1007/s10886-006-9350-2.

45. Tomizawa M., Casida J.E. 2005. Neonicotinoid insecticide toxicology: Mechanisms of selective action. Annual Review of Pharmacology and Toxicology. 45, 247-268. doi: 10.1146/annurev.pharmtox.45.120403.095930

46. Underwood R.M., Currie R.W. 2003. The effects of temperature and dose of formic acid on treatment efficacy against Varroa destructor (Acari: Varroidae), a parasite of Apis mellifera (Hymenoptera: Apidae). Experimental and Applied Acarology, 29, 3-4, 303-313. doi: 10.1023/A:1025892906393.

47. Wu J. Y, Anelli C. M., Sheppard W.S. 2011. Sub-lethal effects of pesticide residues in brood comb on worker honey bee (Apis mellifera) development and longevity. PLoS One, 6, e14720. doi: 10.1371/journal.pone.0014720.

48. Zaluski R., Kadri M. S., Alonso D.P., Martins Ribolla P. E., de Oliveira Orsi R. 2015. Fipronil promotes motor and behavioral changes in honey bees (Apis mellifera) and affects the development of colonies exposed to sublethal doses. Environmental Toxicology and Chemistry, 34, 5, 10621069. doi: 10.1002/etc.2889.

49. Zhang M., Bian K., Zhou T., Song X., Liu Q., Meng C., He L. 2016. Determination of residual fipronil in chicken egg and muscle by LCMS/MS. Journal of Chromatography B: Analytical Technologies in the Biomedical and Life Sciences, 1014, 31-36. doi: 10.1016/j.jchromb.2016.01.041.

Received: 08.12.2021.

Accepted: 29.12.2021. 